\title{
Genetic Study of Sample of 70 Patients with Myasthenia Gravis
}

\author{
ANNE JACOB, ENID R. CLACK, and ALAN E. H. EMERY \\ From University Department of Medical Genetics, Manchester Royal Infirmary, Manchester
}

The role of genetic factors in the causation of myasthenia gravis is not clear. Oppenheim, as early as 1900 , reported familial instances of myasthenia and suggested that genetic factors were involved. On the other hand, Ford in 1937 stated, 'there is never any familial or hereditary tendency in myasthenia gravis'. However, since then, there have been several reports of familial instances of myasthenia gravis (Rothbart, 1937; Osserman, 1958; Goulon et al., 1960; Simpson, 1964; Greenberg, 1964), which have been the subject of several reviews (Celesia, 1965; Kurland and Alter, 1960). Storm-Mathison in 1961 (quoted by Herrmann, 1966) found two secondary cases of myasthenia gravis among the relatives of 88 patients, and Herrmann (1966) found 6 secondary cases among the relatives of 194 patients, but in neither of these surveys were figures given for the number of unaffected relatives. There does not appear to have been a report of any previous study where an attempt was made to determine the actual prevalence of myasthenia gravis among the relatives of affected individuals.

In the present study data were collected on maternal and paternal age, birth order, $\mathrm{ABO}$ and Rhesus blood groups, secretor status, and PTC tasting in patients with myasthenia gravis. The prevalence of the disease among the relatives of 70 patients was studied.

\section{Subjects and Methods}

Seventy patients who had been diagnosed at the Neurological Clinic of the Manchester Royal Infirmary as having myasthenia gravis were investigated. Only cases where the diagnosis was firmly established were included in the survey, and in none of these patients was there any evidence that the myasthenia was secondary to an associated malignancy. All the patients were interviewed personally and extensive family histories were taken. Information on a relative was considered 'reliable' if the relative was seen personally or if the information was provided by a physician, or the informant had seen the relative within the past 2 years. 'Reliable'

Received February 12, 1968. information was obtained on $448(33.6 \%)$ relatives of the 70 probands (Table I).

Maternal and paternal age effects were assessed according to the method of Penrose (1939) and the method of Haldane and Smith (1947) was used for the analysis of birth order.

ABO and Rhesus blood groups were determined in the Clinical Pathology Laboratory at Manchester Royal Infirmary by kind permission of Dr. J. E. MacIver, and the resulting data were compared with a control population obtained from the Manchester area. The values for secretor status were also assessed in the same laboratory, using standard methods, and the resulting proportion of non-secretors was compared with the proportion of non-secretors obtained from pooled data of several European populations (Race and Sanger, 1954).

The method of Harris and Kalmus (1949) was used to assess the ability to taste PTC. A class of university students was used as a control population.

\section{Results}

In the present study no familial case of myasthenia was found among any of the $\mathbf{4 4 8}$ relatives on whom 'reliable' information was available. Neither was there any consanguinity. Among the probands, $91 \%$ had developed the disease by the age of 60 . Of these relatives on whom there was reliable information, $135(32.3 \%)$ had reached the age of 60 but none had developed myasthenia gravis. The percentage distribution of the age of onset of the condition among the 70 probands is given in Fig. 1. In one family, a woman with myasthenia

TABLE I

RELATIVES IN WHOM 'RELIABLE' INFORMATION WAS AVAILABLE

\begin{tabular}{l|r|r|r|r}
\hline \multicolumn{1}{c|}{ Relative } & Total & $\begin{array}{r}\text { No. } \\
\text { Reliable' }\end{array}$ & $\begin{array}{r}\text { No. } \\
\text { over } 60\end{array}$ & $\begin{array}{r}\text { No. } \\
\text { under 60 }\end{array}$ \\
\cline { 2 - 3 } Parents & 140 & 28 & 24 & 4 \\
Offspring & 95 & 89 & 0 & 89 \\
Sibs & 267 & 182 & 52 & 130 \\
Step-sibs & 14 & 10 & 1 & 9 \\
Paternal sibs & 162 & 29 & 16 & 13 \\
Paternal step-sibs & 6 & 4 & 4 & 0 \\
Maternal sibs & 195 & 47 & 38 & 9 \\
Paternal cousins & 189 & 18 & 0 & 18 \\
Maternal cousins & 265 & 41 & 0 & 41 \\
\hline \multicolumn{1}{c|}{ Total } & 1333 & 448 & 135 & 313 \\
\hline
\end{tabular}


gravis had a son with congenital ptosis of the left eye, but there was no evidence that he had myasthenia. The mother first developed symptoms of myasthenia when her son was 11 years old. The son is now 20 years of age and is in good health.

With regard to maternal and paternal age effects, the mean maternal age of 43 patients was 29.6 years and that of their unaffected sibs was $31 \cdot 1$ years. The mean paternal age of the patients was 31.6 years and that of the unaffected sibs was 32.7 years. The differences are not significant. There would, therefore, appear to be no apparent parental age effect.

Following the method of Haldane and Smith (1947) for estimating the effect of birth order, in studies on 69 cases the difference between the mean total of the actual values of birth order (1302) and the mean total of the estimated values (1236) was not significant. There, therefore, appears to be no birth order effect.

The distribution of the $A, O$, and $(A B+B)$ groups in the patients was compared with that of a normal population ${ }^{\star}$ from the same area (Table II). In all three categories there was no significant difference between the patients and the controls.

The distribution of the Rhesus blood groups in patients and in a control population of blood donors from the Manchester area is given in Table II. The difference between the patients and the control population is not significant.

The proportion of non-secretors among the patients with myasthenia gravis $(7 / 21$ or $33.3 \%$ ) was not significantly different from the proportion found in several populations of healthy Europeans: $542 / 2858$ or $23.8 \%$ (Race and Sanger, 1954).

Tests for PTC tasting were carried out on 50 patients and compared with the finding in 50 controls. The threshold values were corrected for age, as suggested by Harris and Kalmus (1949). $70 \%$ of the controls and $74 \%$ of the patients were tasters. The difference between the two groups was not significant.

\section{Discussion}

The distribution of the age of onset in this particular sample of patients is in agreement with the observations of Schwab and Leland (1953), that the age of onset in females tends to occur in the earlier decades and that of males in the later decades. In this study in no decade was the difference in the age of onset of male and female cases significant. The

* Figures for the $\mathrm{ABO}$ distribution in the Manchester area were kindly supplied by Dr. F. Stratton of the National Blood Transfusion Unit, Manchester. Figures for the Rhesus distribution in the Manchester area were kindly supplied by Dr. Ada Copec, Serological Genetics Laboratory, London E.C.4.

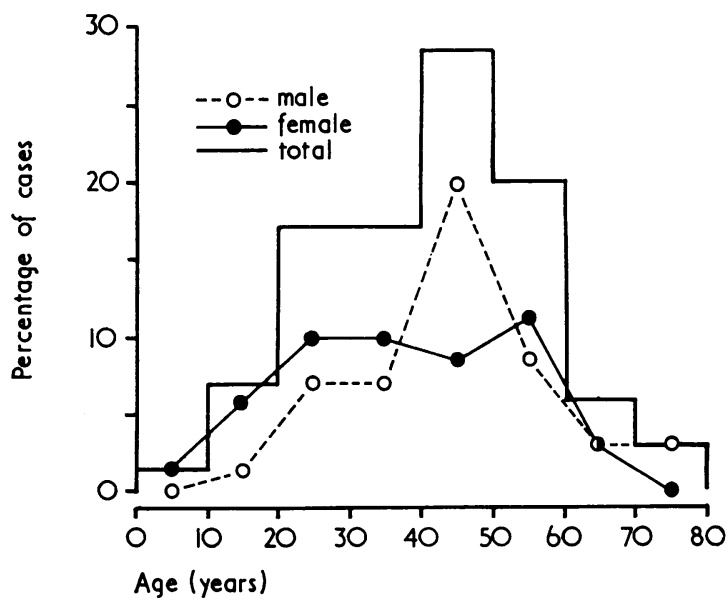

Fig. 1. Percentage distribution of age of onset among 70 probands studied.

distribution of the age of onset in the present study differs from the findings in some earlier studies (Schwab and Leland, 1953; Osserman, 1958; Garland and Clark, 1956). The significantly greater proportion of patients with onset in the sixth or subsequent decades in the series of Osserman (1958) and Schwab and Leland (1953) might be due to the inclusion of cases in which the myasthenic syndrome was secondary to bronchogenic carcinoma (Lambert Okihiro, and Rooke, 1964). The greater proo portion of younger patients in two of the studiest (Osserman, 1958; Schwab and Leland, 1953) may be due to several factors: (a) to bias in selection of sample due to the interest of the physician in juvenile cases, (b) to the incorporation in the study of neonatal cases of myasthenia gravis, and (c) to the inclusion of familial cases of myasthenia, which tend to have an earlier age of onset.

There have been many reports of familial cases of

TABLE II

DISTRIBUTION OF ABO AND RHESUS BLOOD GROUPS AMONG 39 PATIENTS

WITH MYASTHENIA GRAVIS AND A CONTROL POPULATION

\begin{tabular}{|c|c|c|c|c|c|}
\hline & \multicolumn{4}{|c|}{ Group } & \multirow{2}{*}{ Total } \\
\hline & A & \multicolumn{2}{|c|}{$\mathbf{O}$} & $\mathbf{A B}+\mathbf{B}$ & \\
\hline Patients & $\begin{array}{c}18 \\
(46 \cdot 1 \%)\end{array}$ & \multicolumn{2}{|c|}{$\begin{array}{c}15 \\
(38.5 \%)\end{array}$} & $\begin{array}{c}6 \\
(15 \cdot 4 \%)\end{array}$ & 39 \\
\hline \multirow[t]{2}{*}{ Controls } & $\begin{array}{c}3775 \\
(40 \cdot 3 \%)\end{array}$ & \multicolumn{2}{|c|}{$\begin{array}{c}4532 \\
(48 \cdot 4 \%)\end{array}$} & $(11.3 \%)$ & 9370 \\
\hline & \multicolumn{2}{|l|}{$\mathbf{R h}+$} & \multicolumn{2}{|r|}{$\mathbf{R h}-$} & Total \\
\hline Patients & \multicolumn{2}{|c|}{$36(92 \cdot 3 \%)$} & \multicolumn{2}{|r|}{$3 \quad(7 \cdot 7 \%)$} & 39 \\
\hline Controls & \multicolumn{2}{|c|}{$22,570(81 \cdot 4 \%)$} & \multicolumn{2}{|c|}{$5158(18.6 \%)$} & 27,728 \\
\hline
\end{tabular}


myasthenia gravis (see Appendix). Fig. 2 gives the distribution of the age of onset in these familial cases. Using the Wilcoxon-Mann Whitney nonparametric $U$ test the distribution was found to be significantly different from that of our nonfamilial sample (Fig. 1). This suggests that the familial and non-familial forms of myasthenia

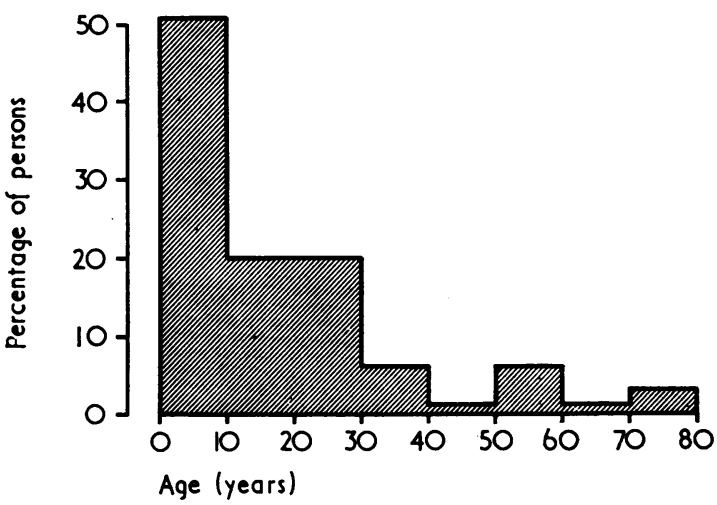

Fig. 2. Percentage distribution of age of onset among 69 familial cases of myasthenia gravis from the literature, where the age of onset has been clearly stated.

gravis might be different entities, the familial form having an earlier age of onset. No significant difference was found between the age of onset distribution of cases in which the condition appeared to be inherited as an autosomal dominant trait, and the distribution of those cases which appeared to be inherited as an autosomal recessive trait. The presentation of the reports of 'familial' myasthenia gravis in the literature was found to be inadequate for genetic analysis, which was also the conclusion of Kurland and Alter (1960).

There have been several reports of myasthenia gravis being associated with a variety of thyroid disorders, including non-toxic nodular goitre with lymphoid infiltration (Ringhertz, 1951), hyperthyroidism (Cohen and King, 1932; McEarhern and Parnell, 1948; Millikan and Haines, 1953), Hashimoto's disease (Simpson, 1964; Daly and Jackson, 1964; Becker et al., 1964), and hypothyroidism (Feinberg, Underdahl, and Eaton, 1957). Patients with thyroid disorders often have a PTC threshold which differs from that found in normal persons (Kitchin et al., 1959; Harris and Kalmus, 1949; Harris, Kalmus, and Trotter, 1949; Fraser, 1961). In the present study, however, no association was found between the ability to taste PTC and myasthenia gravis.

\section{Summary}

In the present study of 70 patients with myasthenia gravis no secondary cases of this disease were found among 448 relatives on whom there was reliable information. No maternal or paternal age effect was shown and no association was found between myasthenia gravis and the ABO and Rhesus blood groups, secretor status, or the ability to taste PTC. The age of onset distribution of this 'non familial' sample was found to be significantly different from that of familial cases taken from the literature.

We should like to thank Dr. G. E. Smyth and Dr. L. A. Liversedge of the Neurological Department, Manchester Royal Infirmary, for permission to study patients under their care.

A. J. was in receipt of an M.R.C. research scholarship. The work was supported by a research grant from the Muscular Dystrophy Group of Great Britain.

\section{REFERBNCES}

Adler, E. (1966). Myasthenia gravis bei eineiigen Zwillingen. Disch. med. Wschr., 91, 396.

Becker, K. L., Titus, J. L., McConahey, W. M., and Woolner, L. B. (1964). Morphological evidence of thyroiditis in myasthenia gravis. F. Amer. med. Ass., 187, 994.

Bornstein, B. (1953). Familial early infantile myasthenia gravis. Acta paediat. (Uppsala), 42, 442.

Bowman, J. R. (1948). Myasthenia gravis in young children; a report of three cases, one congenital. Pediatrics, 1, 472.

Celesia, G. H. (1965). Myasthenia gravis in two siblings. Arch. Neurol. (Chic.), 12. 206.

Cohen, S. J. and King, F. H. (1932). Relationship between myasthenia gravis and exophthalmic goitre. Arch. Neurol. Psychiat. (Chic.), 28, 1338.

Daly, J. J., and Jackson, E. (1964). Case of Hashimoto's disease with myasthenia gravis. Brit. med. $\mathcal{F}$., 1, 748.

Eaton, L. M. (1947). Personal communication to Levin (1949).

Feinberg, W. D., Underdahl, L. O., and Eaton, L. M. (1957). Myasthenia gravis and myxedema. Proc. Mayo Clin., 32, 299.

Foldes, F. F., and McNall, P. G. (1960). Unusual familial occurrence of myasthenia gravis. $\mathcal{F}$. Amer. med. Ass., 174, 418.

Ford, F. R. (1937). Diseases of the Nervous System in Infancy, Childhood and Adolescence. Charles C. Thomas, Springfield,
Illinois.

Fraser, G. R. (1961). Cretinism and taste sensitivity to phenylthiocarbamide. Lancet, 1, 964.

Garland, H., and Clark, A. N. G. (1956). Myasthenia gravis. A personal study of 60 cases. Brit. med. f., 1, 1259.

Goulon, M., Tournilhac, M., Lorin, M. C., and Nouailhat, F. (1960). Myasthénie familiale (à propos de deux soeurs atteintes de myasthénie). Rev. neurol., $103,109$.

Greenberg, J. (1964). Myasthenia gravis and hyperthyroidism in two sisters. Arch. Neurol. (Chic.), 11, 219.

Haldane, J. B. S., and Smith, C. A. B. (1947). A simple exact test for birth order effect. Ann. Eugen. (Lond), 14, 117.

Harris, H., and Kalmus, H. (1949). The measurement of taste sensitivity to phenylthiourea. ibid., $15,24$.

- $\longrightarrow$, and Trotter, W. R. (1949). Taste sensitivity to phenylthiourea in goitre and diabetes. Lancet, $2,1038$.

Hart, H. H. (1927). Myasthenia gravis with ophthalmoplegia and constitutional abnormalities in sisters. Arch. Neurol. Psychiat. (Chic.), 18, 439.

Herrmann, C. (1966). Myasthenia gravis occurring in families. Neurology (Minneap.), 16, 75.

Kitchin, F. D., Howel-Evans, W., Clarke, C. A., McConnell, R. B., and Sheppard, P. M. (1959). P.T.C. taste response and thyroid disease. Brit. med. F., 1, 1069.

Kurland, L. T., and Alter, M. (1960). Current status of epidemiology and genetics of myasthenia gravis. In Myasthenia Gravis. 2nd international symposium proceedings, p. 307 . Ed. by H. R. Viets. Charles C. Thomas, Springfield, Illinois.

Lambert, E. H., Okihiro," M., and Rooke, D. (1964). Clinical physiology of the neuromuscular junction. In 'Muscle'; Proceedings of the Symposium held at Faculty of Medicine, University of Alberta, p. 487. Ed. by M. Paul, E. E. Daniel, C. M. Kay, and G. Monckton. Pergamon Press, London. 
Levin, P. M. (1949). Congenital myasthenia in siblings. Arch. Neurol. Psychiat. (Chic.), $62,745$.

McEarhern, D., and Parnell, J. L. (1948). The relationship of hyperthyroidism to myasthenia gravis. f. clin. Endocr., 8, 842.

Macrae, D. (1954). Myasthenia gravis in early childhood. Pediatrics, 13, 511.

Mancusi-Ungaro, L. (1945). Familial myasthenia gravis. Ann intern. Med., 23, 249.

Marinesco, G. (1908). Contribution à l'étude de la myasthénie grave pseudoparalytique. Sem. méd. (Paris), 28, 421.

Millikan, C. H., and Haines, S. F. (1953). The thyroid gland in relation to neuromuscular disease. Arch. intern. Med., 92, 5.

Noyes, A. P. (1930). Case of myasthenia gravis with certain unusual features. R. I. med.f., 13, 52.

Oppenheim, H. (1900). Diseases of the Nervous System, p. 650. Translated by E. E. Mayer from 2nd German edition. J. B. Lippincott, Philadelphia.

Osborne, D., and Simcock, J. (1966). Myasthenia gravis in identical twins. Brit. med. F., 1, 1025.

Osserman, K. E. (1958). Myasthenia Gravis. Grune and Stratton. New York.

Penrose, L. S. (1939). Maternal age, order of birth and developmental abnormalities. f. ment. Sci., 85, 1141.
Peters, A. (1906). Über Myasthenia und Ptosis. KorrespBl. allg. mecklenburg. Aerztever., Rostock: 5, 242.

Race, R. R., and Sanger, R. (1954). Blood Groups in Man, 2nd ed. Blackwell, Oxford.

Riley, H. A., and Frocht, N. (1943). Myasthenia gravis: Familial occurrence. Arch. Neurol. Psychiat. (Chic.), 49, 905.

Ringhertz, N. (1951). Pathology of the thymus and other organs in myasthenia gravis. Acta path. microbiol. scand., 29, 9.

Rothbart, H. H. (1937). Myasthenia gravis in children-its familial incidence. $f$. Amer. med. Ass., 108, 715.

Schwab, R. S., and Leland, C. C. (1953). Sex and age in myasthenia gravis as critical factors in incidence and remission. ibid., 153, 1270.

Simpson, J. A. (1964). Myasthenia gravis. A thesis presented for the degree of M.D., University of Glasgow.

Storm-Mathison, A. (1961). Myasthenia Gravis. A Clinical Study with Special Reference to Prevalence and Prognosis. Aschehoug, Oslo; Almqvist and Wiksell, Stockholm.

Walsh, F. B., and Hoyt, W. F. (1959). External opthalmoplegia as part of congenital myasthenia in siblings. Myasthenia gravis in children. Report of a family showing congenital myasthenia. Amer. F. Ophthal., 47 (5 part II), 28.

\section{Appendix}

Analysis of 69 Reported Cases of Familial Myasthenia Gravis

(Cases have been included only where Age of Onset was clearly stated)

$\mathrm{DZ}=$ dizygotic twin; $\mathrm{MZ}=$ monozygotic twin; Congenital cases scored as $\mathrm{O}$; $\mathrm{NI}=$ No clear information in literature.

\section{A: SIBS ONLY AFFECTED}

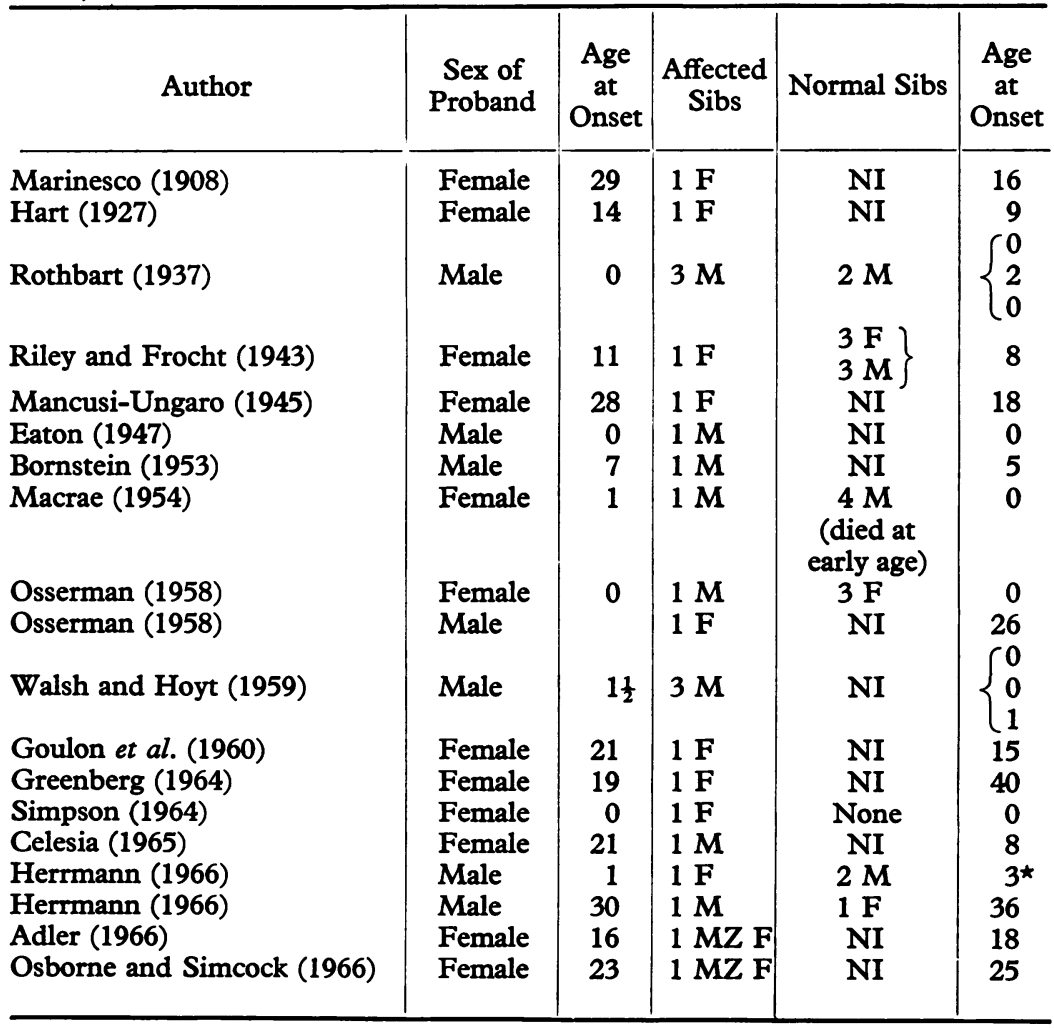


B: AFFECTION IN PARENT AND OFFSPRING OR SOME DISTANT RELATIVE

\begin{tabular}{|c|c|c|c|c|c|c|c|c|}
\hline Author & Sex & $\begin{array}{l}\text { Age } \\
\text { at } \\
\text { Onset }\end{array}$ & $\begin{array}{l}\text { Affected } \\
\text { Sibs }\end{array}$ & $\begin{array}{l}\text { Normal } \\
\text { Sibs }\end{array}$ & $\begin{array}{l}\text { Age } \\
\text { at } \\
\text { Onset }\end{array}$ & $\begin{array}{l}\text { Parent } \\
\text { Affected }\end{array}$ & $\begin{array}{c}\text { Other } \\
\text { Relation Affected }\end{array}$ & $\begin{array}{l}\text { Age } \\
\text { at } \\
\text { Onset }\end{array}$ \\
\hline Peters (1906) & Female & NI & $\begin{array}{l}1 \mathrm{~F} \\
2 \mathrm{M}\end{array}$ & $1 \mathrm{M}$ & $\left\{\begin{array}{l}\mathrm{NI} \\
44 \\
18\end{array}\right.$ & $1 \mathrm{M}$ & NI & NI \\
\hline $\begin{array}{l}\text { Noyes (1930) } \\
\text { Bowman (1948) }\end{array}$ & $\begin{array}{l}\text { Female } \\
\text { Male }\end{array}$ & $\begin{array}{l}55 \\
3 \frac{1}{2}\end{array}$ & $\begin{array}{l}1 \mathrm{M} \\
\text { None }\end{array}$ & $2 \stackrel{N I}{M}$ & 60 & $\begin{array}{l}1 \mathrm{M} \\
\text { None }\end{array}$ & $\begin{array}{l}\mathrm{NI} \\
1 \mathrm{~F}\end{array}$ & $\begin{array}{r}\mathrm{NI} \\
4\end{array}$ \\
\hline Levin (1949) & Female & 0 & $1 \mathrm{M}$ & None & 0 & None & $\begin{array}{l}\text { (maternal cousin) } \\
2 \text { (sex not given) } \\
1 \text { st cousins }\end{array}$ & $\begin{array}{l}0 \\
0\end{array}$ \\
\hline $\begin{array}{l}\text { Osserman (1958) } \\
\text { Osserman (1958) }\end{array}$ & $\begin{array}{l}\text { Male } \\
\text { Female }\end{array}$ & $\begin{array}{l}2 \\
7\end{array}$ & $\begin{array}{l}\text { None } \\
\text { None }\end{array}$ & $\begin{array}{l}\text { None } \\
\text { None }\end{array}$ & & $\begin{array}{l}1 \mathrm{~F} \\
\text { None }\end{array}$ & $\begin{array}{l}\text { NI } \\
1 \mathrm{~F}\end{array}$ & $\begin{array}{c}\mathrm{NI} \\
0\end{array}$ \\
\hline Osserman (1958) & Female & 0 & $1 M$ & $\begin{array}{l}1 \mathrm{DZM} \\
1 \mathrm{M}\end{array}$ & 0 & None & $\begin{array}{c}\text { (paternal cousin) } \\
1 \mathrm{M} \\
\text { (maternal cousin) }\end{array}$ & $11 \dagger$ \\
\hline $\begin{array}{l}\text { Foldes and McNall (1960) } \\
\text { Simpson (1964) }\end{array}$ & $\begin{array}{l}\text { Female } \\
\text { Female }\end{array}$ & $\begin{array}{l}27 \\
22\end{array}$ & $\begin{array}{l}1 \mathrm{~F} \\
\text { None }\end{array}$ & $5^{\text {None }}$ & 37 & $\begin{array}{l}1 \mathrm{M} \\
\text { None }\end{array}$ & $\begin{array}{l}\text { None } \\
1 \mathrm{M}\end{array}$ & $\begin{array}{c}17 \\
\mathrm{NI}\end{array}$ \\
\hline Herrmann (1966) & Female & 67 & None & NI & & None & $\begin{array}{c}\text { (1st cousin once } \\
\text { removed) } \\
1 \mathrm{~F} \\
\text { (half-brother's } \\
\text { daughter) }\end{array}$ & 30 's \\
\hline Herrmann (1966) & Female & 55 & None & NI & & None & $\begin{array}{c}1 M \\
\text { (2nd cousin) }\end{array}$ & 71 \\
\hline Herrmann (1966) & Female & 51 & None & NI & & None & $\begin{array}{c}1 \mathrm{~F} \\
\text { (maternal aunt's }\end{array}$ & 77 \\
\hline Herrmann (1966) & Male & $8 \frac{1}{2}$ & None & NI & & $1 \mathrm{M}$ & $\begin{array}{l}\text { daughter) } \\
\text { None }\end{array}$ & 26 \\
\hline
\end{tabular}

* May have had drooping of eyelids at 3 but generalized weakness definitely established by 6 .

t Parents were first cousins. 